\title{
STUDI DESKRIPTIF MINAT MAHASISWA STT KAO TENTANG PENGEMBANGAN KARUNIA ROH KUDUS DALAM PELAYANAN PEMBERITAAN INJIL
}

\author{
Dr. Chandra Kirana Luhur, M. Pd \\ (Dosen Prodi Teologi STT KAO Semarang : chandra@sttkao.ac.id)
}

\begin{abstract}
Carrying out the mission of the great commission is a general church task, which must be carried out by all believers. Conducting missions in the 4.0 era is a challenge in itself, and the university must empower the student with the gift of the Holy Spirit who can answer the needs of mission services in this era. The research is a quantitative research, applying descriptive and phenomenological methods to show a description of service needs related to mission in the 4.0 era. As a result, a leader,must first be empowered in terms of gifts so as to optimize the gifts that are in the students.
\end{abstract}

Keywords : Gift of the Holy Spirit, Mission Services

\section{A. PENDAhuluan}

Misi Kristus tentang Amanat Agung merupakan bagian dari kehidupan orang Kristen. Seorang Kristen dalam pengertian yang mendasar. Kekristenan yang dimulai dari panggilan pertobatan hingga pada proses hidup baru, harus memahami dirinya adalah sebagai agen dari misi Allah yang diekspresikan dalam seruan Amanat Agung. Artinya, misi Amanat Agung tidak lagi dilihat sebagai tugas eksklusif bagi sebagian orang Kristen yang memiliki kerinduan atau panggilan akan misi tersebut. Tugas ini adalah bagian dari panggilan kekristenan bagi setiap orang Kristen, bahwa mereka harus menjadi saksi, garam, terang, sehingga membawa orang lain kepada iman di dalam Yesus Kristus.

Pengertian kerinduan memberikan implikasi bahwa adalah hal yang sah dan wajar saja jika ada orang Kristen yang tidak memiliki kerinduan akan misi Amanat Agung tersebut. Kerinduan memberi kesan akan adanya opsi atau tawaran bagi yang mau saja dan yang ingin melakukannya. Begitu juga jika Amanat Agung dipahami sebagai sebuah panggilan khusus bagi orang-orang tertentu, maka hanya orang-orang yang memiliki panggilan itu saja yang akan melakukannya. Padahal Amanat Agung yang umum dipahami dalam Matius 28:18-20 adalah tidak diberikan hanya kepada 11 murid atau rasul yang tersisa saja, melainkan semua orang yang mengikuti Yesus sebelum Ia terangkat ke Sorga; Kisah Para Rasul mengindikasikan ada sekitar 120 orang. Namun, masih saja ada orang Kristen yang beranggapan bahwa itu adalah tugas para hamba Tuhan. 
Tujuan dari pembahasan ini adalah menunjukkan sebuah tanggung jawab STT untuk meningkatkan kegiatan misi melalui pemberdayaan mahasiswa dengan karunia-karunia Roh Kudus. Pembahasan ini penting mengingat kegiatan misi yang seolah-olah mengalami stagnasi oleh karena banyaknya rintangan melalui regulasi yang diterapkan di berbagai daerah. Handreas Hartono berpendapat bahwa melakukan misi Amanat Agung di masa sekarang harus memperhatikan konteks dunia saat ini, bukan hanya berpatokan pada masamasa lalu hingga ke zaman para rasul. ${ }^{1}$ Tantangan sejatinya membuahkan kesempatan, atau setidaknya stimulus untuk sebuah kesempatan.

Tuhan menghendaki supaya setiap orang percaya bukan hanya mengetahui bahwa “ada karunia Roh Kudus", tetapi juga supaya "mengetahui kebenaran tentang karunia Roh Kudus". Karena ada pemahaman yang benar dan ada pemahaman yang keliru. Setiap manusia format alamiahnya dikendalikan oleh unsur jiwani. Oleh karena itu kita harus penuh Roh Kudus dengan cara menjaga "hubungan" dengan Roh Kudus. "Hubungan” dengan Roh Kudus berarti bahwa kita bukan hanya menjaga "persekutuan" dengan Roh Kudus di kamar doa, tetapi juga saat kita sedang beraktivitas kita tetap menjaga "hubungan” dengan Roh Kudus, kita hidup dipimpin oleh Roh Kudus. Kita harus memahami hal ini lebih dulu.

Kemajuan zaman dengan digitalisasi telah menghasilkan sebuah dunia baru, yakni dunia maya, di mana dapat menjadi peluang bagi gereja untuk melakukan pelayanan misi di dunia maya tersebut. Kegiatan misi tersebut harus mempertimbangkan kemampuan atau sumber daya yang ada di dalam gereja agar dapat menggunakan tantangan menjadi kesempatan. Itulah sebabnya penting untuk gereja dapat memberdayakan jemaat untuk dapat melakukan misi.

Peneliti melakukan pengamatan mengenai minat para mahasiswa STT Kristus Alfa Omega Semarang yang sampai saat ini sudah melaksanakan beberapa kali pertemuan untuk pelatihan pemberdayaan karunia-karunia Roh Kudus. Banyak peserta yang antusias untuk mengikuti pelatihan ini dan terjadi beberapa terobosan dalam pengenalan mereka akan karunia Roh Kudus yang selama ini belum mereka pahami dengan baik. Banyak kendala yang dialami oleh pengurus berkaitan dengan pelaksanaan pelatihan ini karena hal ini merupakan sesuatu yang baru bagi para peserta yang terlibat di dalamnya terutama dalam hal pemberdayaan setiap karunia yang Tuhan berikan kepada setiap mereka. Pemahaman yang

${ }^{1}$ Handreas Hartono, "Mengaktualisasikan Amanat Agung Matius 28: 19-20 Dalam Konteks Era Digital, ” KURIOS (Jurnal Teologi dan Pendidikan Agama Kristen) 4, no. 2 (2018): 169, www.sttpb.ac.id/e-journal/index.php/kurios. 
berbeda terkadang juga menjadi kendala di dalam respon setiap mahasiswa sehingga perlu dilakukan pengajaran secara benar dan Alkitabiah sehingga mereka semua menjadi satu dalam persepsi maupun pemahamannya.

Latar belakang yang diperkirakan paling mempengaruhi implementasi minat mahasiswa di dalam penerapan karunia Roh Kudus di dalam penginjilan adalah pemahaman yang benar sehingga dengan memiliki pemahaman yang benar mereka akan bisa melaksanakan penginjilan dengan menggunakan karunia Roh Kudus dengan baik dan maksimal. Mahasiswa STT KAO Semarang berasal dari berbagai daerah di Indonesia dengan berbagai latar belakang denominasi gereja sehingga pengajaran doktrin tentang karunia Roh Kudus sangat beragam.

Pelatihan pemberdayaan karunia-karunia Roh Kudus untuk penjangkauan jiwa ini mendapat dukungan dari para pemimpin STT KAO sehingga dalam pelaksanaan pelatihan maupun persiapan anggaran beaya yang dibutuhkan untuk pertemuan ini lebih mudah diatasi. Persoalan yang muncul adalah kurangnya dosen atau tenaga pengajar yang memiliki karunia Roh Kudus sehingga di dalam pelatihan ini seringkali harus mendatangkan pembimbing dari luar STT yang tentunya juga tidak bisa dilaksanakan dengan mudah karena harus menyesuaikan waktu pembimbing tersebut dengan waktu pelatihan yang dilaksanakan di STT KAO.

Pelatihan pemberdayaan karunia ini melibatkan mahasiswa dari seluruh Angkatan dan dari seluruh prodi yang berminat. Pelatihan ini bukan sebuah keharusan tetapi dikhususkan bagi setiap mereka yang berminat dan rindu untuk dapat melakukan penginjilan dengan pemberdayaan karunia-karunia Roh Kudus. Karena mahasiswa yang terlibat adalah dari seluruh Angkatan maka daya serap pemahaman merekapun berbeda-beda, ada yang merespon dengan cepat dan ada juga yang sangat lambat.

\section{B. METODOLOGI}

Berdasarkan permasalahan penelitian ini yang akan dianalisa, maka ancangan penelitian yang digunakan adalah ancangan positivis. Adapun yang dimaksud dengan ancangan positivis adalah penyelidikan dengan menggunakan metode ilmiah, yaitu prosedur langkah demi langkah dalam memecahkan masalah penelitian atas dasar pengamatan empiris. Sedangkan rancangan penelitian yang digunakan adalah kuantitatif bukan eksperimental, yaitu dengan melakukan penelitian studi deskriptif. Sugiyono juga menjelaskan bahwa 
metode kuantitatif juga disebut metode konfirmatif, karena metode ini digunakan untuk melakukan pembuktian/ konfirmasi teori terhadap fakta empiris di lapangan.

Studi deskriptif adalah adalah salah satu jenis penelitian kuantitatif yang berfokus pada pengumpulan data angka. Penelitian deskriptif adalah suatu metode penelitian yang ditujukan untuk menggambarkan fenomena yang ada, yang berlangsung pada saat ini atau saat yang telah lalu. Jenis penelitian studi deskriptif digunakan untuk memotret data apa adanya tentang studi deskriptif minat mahasiswa STT KAO tentang pengembangan karunia Roh Kudus dalam pelayanan pemberitaan Injil . Jadi rumusan masalah penelitian ini menggunakan pendekatan deskriptif kuantitatif untuk mencari nilai seberapa besar tingkat kecenderungan minat mahasiswa STT KAO tentang pengembangan karunia Roh Kudus dalam pelayanan pemberitaan Injil?

Adapun yang menjadi sumber data atau sumber informasi dalam penelitian ini, yaitu yang berfungsi sebagai pemberi penilaian tentang minat mahasiswa STT KAO tentang pengembangan karunia Roh Kudus dalam pelayanan pemberitaan Injil adalah para mahasiswa yang sudah bergabung di dalam kelompok pengembangan karunia Roh Kudus sebanyak 20 orang. Jumlah angket yang kembali adalah sebanyak 20 angket, atau 20 penilaian para peserta. Pada penelitian ini digunakan instrumen untuk mengumpulkan penilaian responden tentang subjek riset atau unit analisis yaitu materi pengenalan akan Kristus dalam pemuridan SPK. Instrumen yang dimaksud adalah berupa angket tertutup, yang memberikan pernyataan kepada responden, di mana responden menjawabnya dengan cara memberikan tanda check list pada kolom yang tersedia.

Hipotesis ialah pernyataan deklaratif yang menunjukkan adanya kemungkinan hubungan tertentu di antara dua atau lebih variabel yang dapat diuji. Menurut Sarwono hipotesis merupakan jawaban sementara dari pesoalan yang diteliti. Untuk itu rumusan hipotesa dalam penelitian ini, adalah:

i). Diduga tingkat kecenderungan minat mahasiswa dalam pengembangan karunia Roh Kudus dalam pengabaran Injil berada dalam kategori tinggi.

ii). Latar belakang yang paling berpengaruh terhadap minat mahasiswa dalam pengembangan karunia Roh Kudus dalam pengabaran Injil adalah pemahaman yang benar.

Berdasarkan uji hipotesis, maka disimpulkan bahwa hipotesis nol yang berbunyi diduga minat Mahasiswa STT KAO tentang pengembangan karunia Roh Kudus dalam pelayanan pemberitaan Injil adalah pada kategori cukup (= 55\%) atau sama dengan 93,5, 
dinyatakan ditolak. Sedangkan hipotesis alternative yang berbunyi diduga minat Mahasiswa STT KAO tentang pengembangan karunia Roh Kudus dalam pelayanan pemberitaan Injil adalah tidak pada kategori cukup $(\neq 55 \%$ ) atau tidak sama dengan 93,5 , dinyatakan diterima. Setelah dilakukan penghitungan seberapa besar nilai variabel X, maka disimpulkan bahwa nilai variabel X atau variabel Minat Mahasiswa STT KAO tentang Pengembangan Karunia Roh Kudus dalam Pelayanan Pemberitaan Injil adalah 94,4\% (kategori sangat tinggi).

Berdasarkan penghitungan pada hipotesis latar belakang responden yang paling berpengaruh pada variabel Minat Mahasiswa STT KAO tentang Pengembangan Karunia Roh Kudus dalam Pelayanan Pemberitaan Injil, maka disimpulkan bahwa latar belakang "lama berkuliah di STT KAO” menjadi latar belakang yang paling berpengaruh diantara tiga jenis latar belakang responden lainnya. Adapun besaran kuat pengaruh latar belakang "lama berkuliah di STT KAO” terhadap Minat Mahasiswa STT KAO tentang Pengembangan Karunia Roh Kudus dalam Pelayanan Pemberitaan Injil adalah 55,9 \% (kategori cukup).

\section{PEMBAHASAN}

Proses pelatihan pemberdayaan karunia Roh Kudus dengan tujuan untuk pemberitaan Injil bagi jiwa-jiwa merupakan salah satu cara yang bisa dipakai oleh setiap orang percaya untuk menjangkau jiwa-jiwa yang belum bertobat. Istilah karunia Roh Kudus bukan hanya menunjuk kepada 9 jenis karunia yang disebutkan dalam 1 Korintus 12 . Walaupun hal itu juga tidak salah, dan merupakan karunia yang juga dikembangkan dalam gereja mula-mula, namun pembahasan tentang karunia yang perlu dikembangkan dalam pelatihan mahasiswa dalam penelitian ini adalah karunia yang juga disebutkan dalam Roma dan Efesus. Karunia-karunia tersebut diberikan Tuhan bagi gereja-Nya untuk berkembang dan mengoptimalkan pelayanan yang ada di dalam gereja dan masyarakat.

\section{Pengertian Karunia Roh Kudus}

Karunia merupakan kemampuan yang diberikan oleh Allah dalam rangka mengembangkan pelayanan yang dipercayakan kepada hamba-Nya. Kemampuan itu bersifat pemberian, maka itulah sebabnya disebut karunia. Sebuah pemberian yang diberikan kepada orang yang sesungguhnya tidak layak untuk memperolehnya. Karunia harus dibedakan dari kemampuan yang dimiliki oleh seseorang. Karunia berkaitan erat dengan pelayanan, karena sejatinya karunia diberikan dalam rangka untuk melayani Tuhan. Setiap orang percaya memiliki tanggung jawab untuk melakukan pekerjaan yang Tuhan berikan kepada mereka. 
Namun demikian, dalam rangka untuk mengerjakan panggilan tersebut, Allah memberikan kemampuan yang mungkin di luar dari apa yang bisa dilakukan seseorang. Karunia setiap orang berbeda-beda sesuai dengan kebutuhan dan keadaan yang ada di dalam gereja atau tempat di mana seseorang dipanggil untuk melayani.

Pengembangan karunia sangat dibutuhkan oleh orang percaya agar mereka juga dapat berkembang demi mengikuti pola kehidupan kerohanian yang juga mengalami perubahan. Kebutuhan orang percaya yang semakin erat kaitannya dengan pola hidup serba digital ini membutuhkan orang yang dapat melayani Tuhan dan terlibat dalam pekerjaan Tuhan dengan memiliki kemampuan untuk mengaktualisasikan dirinya melalui berkembangnya zaman. Pemberdayaan jemaat harus dimulai dari pemimpin yang telah lebih dahulu berdaya dalam karunia yang dapat diterapkan untuk kegiatan misi di era digital ini.

Stephen Tong mengatakan, "Doktrin ini merupakan suatu konsep yang tidak ada pada agama-agama lain. Bukan suatu konsep yang ditarik sebagai kesimpulan dari hasil pikiran manusia melalui kemampuan rasio. Hal ini merupakan suatu konsep yang tidak dapat dihindari oleh manusia, karena Allah telah demikian menyatakan diri,memperkenalkan diriNya kepada manusia."2 Roh Kudus memiliki ciri-ciri yang hanya dimiliki oleh Allah sendiri. Kisah Para Rasul memberi kesaksian tentang "pencurahan” Roh dan pekerjaan ganda-Nya. J.D. Douglas mengatakan, "Kadang-kadang penekanan terletak pada kekuatan Roh seakanakan ia bertindak secara impersonal. Kadang-kadang Ia bertindak dengan penampilan sebagai personal, di mana Ia tidak dapat dibohongi, dan dalam ayat lain Ia membimbing, memilih, dan menghibur."3 Roh Kudus adalah satu pribadi Allah. Dia adalah Allah yang berdiam dalam orang-orang tebusan dan bekerja di antara orang percaya untuk menggenapi kehendak Allah. Ini merupakan hak istimewa yang penuh berkat dan kemuliaan bagi orangorang percaya untuk memiliki sukacita dan pengetahuan yang disadari akan Roh Kudus yang tinggal di dalamnya.

\section{a. Konsep Alkitab Tentang Karunia Roh Kudus}

Roh Kudus adalah pribadi Tuhan dalam konsep Tritunggal. Roh Kudus (dalam bahasa Ibrani הקודש רוח Ruah haqodesh) hanya dipercayai oleh umat Kristiani dan adalah pribadi penolong yang memimpin kita, dalam bentuk Roh (pneuma, Yun: $\pi v \varepsilon v ́ \mu \alpha$ ) yang

2.

${ }^{2}$ Stephen Tong, Allah Tritunggal ("tk" : Lembaga Reformed Injili Indonesia, 1993),

${ }^{3}$ J.D. Douglas, Ensiklopedi Alkitab Masa Kini Jilid II (Jakarta: Yayasan Komunikasi Bina Kasih OMF, 1995), 320. 
dijanjikan oleh Yesus Kristus sebelum kenaikan-Nya ke Sorga. Menurut ajaran Kristiani, seorang Kristen memiliki Roh Kudus di dalam dirinya. Roh Kudus merupakan Roh Allah yang menolong, memimpin, menghibur, dan menjadi teman yang setia. Roh Kudus menuntun orang percaya agar hidup sejalan dengan kehendak Tuhan. Roh Kudus juga merupakan penghubung antara orang percaya dengan Allah. Roh Kudus adalah pribadi ke 3 dari Allah Tri Tunggal. Ia harus kita cintai dan hormati seperti kita menghormati dan mencintai Allah Bapa dan Tuhan kita Yesus Kristus. Roh Kudus memiliki kuasa yaitu karunia-karunia Roh Kudus yang Yesus rindukan untuk dialirkan melalui hidup kita.

\section{b. Definisi Karunia Roh Kudus}

Peter wagner, seorang pengajar apostolik dan penulis meringkas sifat dan tujuan karunia Roh sebagai berikut: "Karunia Roh adalah ciri khas istimewa yang diberikan oleh Roh Kudus kepada setiap anggota tubuh Kristus, menurut kasih karunia Allah, untuk digunakan dalam konteks tubuh Kristus" ${ }^{4}$ Karunia rohani dapat didefinisikan sebagai "kemampuan khusus yang diberikan kepada orang- orang percaya oleh Roh Kudus untuk memuliakan Kristus dan membangun gereja-Nya”.

\section{c. Jenis-jenis Karunia Roh Kudus}

Karunia-karunia rohani tidak diperoleh karena pekerjaan yang baik, punya talenta atau kemampuan- kemampuan alamiah. Karunia rohani merupakan pemberian dari Tuhan, oleh sebab itu tidak mungkin seseorang mendapatkannya melalui kerja keras, memperoleh karena layak atau mempelajarinya dari buku-buku. Tidak juga bisa didapatkan dengan cara berlatih dan meniru orang lain. Karunia ini adalah mutlak milik Tuhan dan diberikan kepada orang yang rindu melakukan kehendak-Nya dan bertujuan untuk menjangkau jiwa.

Berdasarkan 1 Korintus 12:7-11, kita dapat mengetahui adanya sembilan jenis karunia Roh Kudus yaitu:

i). Berkata-kata dengan Hikmat.

ii). Berkata-kata dengan Pengetahuan

iii). Karunia untuk Menyembuhkan

iv). Karunia Iman

v). Karunia Mengadakan Mukjizat

${ }^{4}$ C. Peter Wagner, Discover Your Spiritual Gift (Ventura, C. A: Regal Books, 2005), 20. 
vi). Karunia bernubuat

vii). Karunia untuk Membedakan Roh.

viii). Karunia Bahasa Roh.

ix). Karunia untuk Menafsirkan Bahasa Roh.

\section{Cara Untuk Menerima Karunia Roh Kudus}

Dalam Alkitab Perjanjian Baru kita mendapat informasi bahwa ada dua cara untuk menerima karunia-karunia Roh itu. Yang pertama adalah melalui baptisan Roh Kudus. Sebelum kenaikan-Nya ke Sorga, Yesus telah berpesan kepada rasul-rasul itu agar tidak meninggalkan Yerusalem karena mereka akan menerima janji Allah, di mana Yohanes membaptis dengan air tetapi mereka akan dibaptis dengan Roh Kudus (Luk 4:48; Mat 3:11; Kis 1:4-5). Bill Hamon berkata bahwa anda harus menerima pewahyuan dan pengertian bahwa karunia itu adalah untuk anda. ${ }^{5}$

Kemudian cara yang ke-dua adalah dengan penumpangan tangan rasul. Orang-orang yang mendapat tumpangan tangan rasul akan mendapat karunia Roh Kudus. Tentu penumpangan itu bukan atas kemauan rasul itu sendiri melainkan Roh Kudus, "Tetapi semuanya ini dikerjakan oleh Roh yang satu dan yang sama, yang memberikan karunia kepada tiap-tiap orang secara khusus, seperti yang dikehendaki-Nya" (1 Kor 12:11). Contohnya: (1) Kisah Rasul 6:1-5, salah satu dari tujuh saudara yang dipilih itu melakukan tanda-tanda mukjizat di Samaria sebagai konsekuensi tumpangan tangan rasul. (2) Kisah Rasul 19:1-7, orang Kristen di Efesus mendapat tumpangan tangan dari Paulus dan mereka bernubuat dan berkata-kata dalam berbagai bahasa.

\section{a. Percaya dan Melekat Kepada Tuhan}

Setiap orang percaya adalah anggota tubuh Kristus yang melekat pada tubuh yaitu pada sebuah gereja lokal. Orang yang sudah menjadi pengikut Kristus tetapi tidak tertanam pada gereja lokal, maka ia tidak akan bertumbuh. Setiap orang setelah bertobat harus langsung mencari gereja lokal dan tertanam di gereja lokal tersebut. Banyak hamba Tuhan yang tidak mengajarkan hal ini. Orang yang baru bertobat langsung melayani di luar gereja dan ini adalah tidak benar. Tidak ada orang yang bertumbuh di luar gereja, karena hanya di dalam gereja lokal orang percaya akan mendapat pengayoman dari otoritas rohani.

${ }^{5}$ Bill Hamon, 70 Alasan Berbahasa Roh (Jakarta: Nafiri Gabriel, 2013), 223. 


\section{b. Pribadi yang Kudus dan Tidak Bercacat}

Pekerjaan Roh Kudus dalam kehidupan kita harus di mulai dari kehidupan pribadi kita lebih dulu baru kemudian pelayanan. Mengapa harus di mulai dari kehidupan pribadi lebih dulu? Karena kitalah orang yang akan melaksanakan pekerjaan pelayanan. Jika kita goncang, maka akan mempengaruhi pelayanan kita. Jika kita kuat, maka akan mempengaruhi pelayanan kita juga. Apa yang terjadi dalam hidup kita, itu yang kita bawa dalam pelayanan. Jika karakter kita sudah dibentuk oleh Roh Kudus, maka itu yang kita bawa dalam pelayanan.

\section{c. Hubungan yang Intim dengan Roh Kudus}

Masih banyak hal yang harus Ku-katakan kepadamu, tetapi sekarang kamu belum dapat menanggungnya. Tetapi apabila Ia datang, yaitu Roh Kebenaran, Ia akan memimpin kamu ke dalam seluruh kebenaran; sebab Ia tidak akan berkata-kata dari diri-Nya sendiri, tetapi segala sesuatu yang didengar-Nya itulah yang akan dikatakan-Nya dan Ia akan memberitakan kepadamu hal-hal yang akan datang. Ia akan memuliakan Aku, sebab Ia akan memberitakan kepadamu apa yang diterimanya dari pada-Ku. Segala sesuatu yang Bapa punya, adalah Aku punya; sebab itu Aku berkata: Ia akan memberitakan kepadamu apa yang diterimanya dari pada-Ku."” Yohanes 16:12-15. Roh Kudus jauh lebih daripada sekedar kekuatan atau kuasa. ${ }^{6}$

\section{Pengembangan Karunia Roh Kudus}

Masing-masing dari kita memiliki karunia khusus untuk menggunakan penjangkauan rohani. Kita semua adalah anak yang dikaruniai karunia Roh Kudus dan kita akan mempertanggung-jawabkan semua yang sudah dipercayakan Tuhan kepada kita. Karena itu, "Layanilah seorang akan yang lain, sesuai dengan karunia yang telah diperoleh tiap-tiap orang sebagai pengurus yang baik dari kasih karunia Allah" (1 Pet 4:10).

a. Memahami Karunia Roh Kudus yang Ada Dalam Diri

Bagaimanakah seorang percaya dapat mengetahui atau menemukan karunia rohaninya? Berikut ini petunjuk-petunjuk yang berguna untuk menemukan karunia-karunia rohani orang percaya:

i). Sadarilah bahwa orang percaya memiliki paling sedikit satu karunia rohani.

\footnotetext{
${ }^{6}$ Benny Hinn, Selamat Datang Roh Kudus (Jakarta: Immanuel, 2004), 25.
} 
ii). Berdoalah tentang hal itu. Mintalah pada Tuhan agar menunjukkan apa karunia rohani kita.

iii). Pelajarilah ayat-ayat Alkitab mengenai karunia-karunia rohani. Allah menyatakan kebenaran melalui firman-Nya.

iv). Terimalah karunia yang Tuhan beri dengan bersyukur. Mengucap syukurlah kepada Tuhan atas karunia yang telah Ia berikan. Janganlah menginginkan karunia yang orang lain miliki. Tidak ada karunia yang kecil di mata Allah karena semuanya penting untuk membangun gereja-Nya.

b. Membangun Karunia Roh Kudus

Setiap anggota tubuh dibutuhkan untuk berfungsi secara menyeluruh. Setiap anggota tubuh Kristus dibutuhkan untuk memenuhi tujuan-Nya di dunia ini. Beberapa hal yang dapat dilakukan untuk membangun karunia-karunia adalah:

i). Izinkan Roh Kudus bebas untuk membangun karunia yang Dia beri dan bersedialah untuk dipakai. Setiap hari mintalah pada Roh Kudus untuk mengisi dan menjadikan kita sebagai berkat. "Dan janganlah kamu mabuk oleh anggur, karena anggur menimbulkan hawa nafsu, tetapi hendaklah kamu penuh dengan Roh" (Ef 5:18).

ii). Terlibatlah dalam pekerjaan dan pelayanan di gereja lokal. Karunia-karunia itu diberikan untuk membangun tubuh Kristus, yaitu gereja. Melalui gereja lokal karunia-karunia rohani itu digunakan untuk melayani.

iii). Melayani dengan kasih. Tunjukkanlah kasih kita kepada Tuhan dengan penggunaan dari setiap karunia rohani. Mulailah hari ini untuk menemukan dan menggunakan karunia rohani yang telah diberikan Tuhan.

c. Pendayagunaan Karunia Roh Kudus

Karunia-karunia Roh adalah salah satu kebenaran yang tidak kalah pentingnya dengan kebenaran-kebenaran yang lain dalam Alkitab. Oleh karena itulah Allah melalui pekerjaan Roh Kudus menggerakkan para penulis Alkitab untuk memasukkan kebenaran tersebut ke dalam Alkitab. Rick Warren dalam bukunya Pertumbuhan Gereja Masa Kini mengatakan, "Allah konsisten dengan rencana-Nya bagi kehidupan kita. ${ }^{7}$ Ia tidak akan memberikan kepada masing-masing kita bakat pembawaan sejak lahir, temperamen, talenta, karunia rohani, pengalaman hidup dan kemudian tidak menggunakannya. Demikian juga

${ }^{7}$ Rick Warren, Pertumbuhan Gereja Masa Kini (Malang: Gandum Mas, 1990), 378. 
dengan karunia-karunia Roh yang dimiliki oleh setiap anggota jemaat adalah sebagai alat untuk melaksanakan pekerjaan pembangunan tubuh Kristus. Tanpa karunia Roh pembangunan tubuh Kristus akan mengalami hambatan bahkan tidak dapat dijalankan. Sebab, karunia-karunia Roh diberikan Allah Tritunggal kepada jemaat-Nya sebagai perlengkapan untuk didayagunakan demi mencapai hasil yang sebesar-besarnya.

\section{Memberitakan Injil Dengan Kuasa Roh Kudus}

Manusia diselamatkan oleh karena Kristus melalui karya penebusan di salib, bukan karena usaha atau perbuatan baik. Efesus 2:8-9 mengatakan, "Sebab karena kasih karunia kamu diselamatkan oleh iman; itu bukan hasil usahamu, tetapi pemberian Allah, itu bukan hasil pekerjaanmu, jangan ada orang yang memegahkan diri” Ketika seseorang menerima Kristus sebagai Tuhan dan Juruselamat, ia dijadikan ciptaan baru (2 Kor 5:17). Bukan hanya itu, setiap orang yang menerima Yesus akan diberi kuasa agar menjadi anak-anak Allah (Yoh 1:12), sehingga orang percaya memiliki hubungan sebagai anak dan Bapa di dalam Kristus.

\section{a. Pemberdayaan Karunia Roh Kudus Dalam Pemberitaan Injil}

Pertumbuhan jemaat adalah dambaan dan harapan Yesus Kristus sebagai Kepala gereja bagi gereja-Nya. Artinya tidak ada alasan untuk gereja tidak bertumbuh. Hal ini sangat jelas melalui pernyataan Yesus dalam Matius 28:18-20, sebagai berikut: Yesus mendekati mereka dan berkata: Kepada-Ku telah diberikan segala kuasa di sorga dan di bumi. Karena itu pergilah, jadikanlah semua bangsa murid-Ku dan baptislah mereka dalam nama Bapa dan Anak dan Roh Kudus, dan ajarlah mereka melakukan segala sesuatu yang telah Kuperintahkan kepadamu. Dan ketahuilah, Aku menyertai kamu senantiasa sampai akhir zaman. Christian A. Schwarz dalam bukunya yang berjudul Pertumbuhan Gereja Alamiah, menemukan delapan karakteristik kualitas dari gereja yang bertumbuh, salah satunya adalah pelayanan yang berorientasi pada karunia. ${ }^{8}$

\section{b. Karya Nyata Roh Kudus Dalam Pemberitaan Injil}

Pekabaran injil adalah amanat Yesus Kristus yang ditugaskan kepada murid-muridNya (gereja-Nya). Dasar dari pekabaran Injil itu adalah perintah dan amanat Kristus. Guna menyelenggarakan pekabaran Injil itulah, Yesus Kristus telah mengutus murid-murid-Nya untuk pergi ke seluruh dunia menjadikan semua bangsa menjadi murid bagi Yesus Kristus

\section{${ }^{8}$ Christian A. Schwarsz, Pertumbuhan Gereja Yang Alamiah (Jakarta: Metanoia} Publishing, 1999). 
dan untuk memberitakan injil itu kepada semua bangsa dan segala makhluk. Pengutusan murid-murid dalam memberitakan Injil tidak akan dapat berjalan dengan baik tanpa Roh Kudus yang bekerja di dalamnya.

\section{c. Pengaruh Kuasa Roh Kudus yang Nyata Dalam Pemberitaan Injil}

Kuasa yang Tuhan berikan adalah kemampuan untuk menghadapi kuasa kegelapan karena kuasa Roh Kudus yang ada di dalam orang percaya lebih besar dari segala roh yang ada di dunia ini (1 Yoh 4:4). Itu berarti bahwa kemenangan dalam melawan kuasa kegelapan telah menjadi jaminan bagi kita. Kuasa dosa, iblis dan maut telah dipatahkan oleh kuasa kebangkitan Yesus Kristus. Kuasa ini pula yang mampu membebaskan orang dari belenggu kuasa kegelapan. Pelayanan Yesus disertai dengan mukjizat dan tanda-tanda ajaib (sign and wonders), sehingga banyak orang yang mengalami pembebasan (deliverance). Iblis akan terus berusaha untuk mencuri, membunuh, dan membinasakan tetapi Tuhan Yesus adalah Gembala yang baik yang memberikan kehidupan yang berkelimpahan (Yoh.10:10).

Orang-orang yang melayani dalam kuasa Allah menjadi berkat bagi banyak orang lain. Mereka dimampukan Tuhan untuk membebaskan banyak orang yang terikat oleh kebiasaan dan dosa tertentu, yang terikat oleh kutuk nenek moyang di masa lalu, yang dirasuk oleh setan. Mukjizat dan tanda bukan tujuan utama dari pelayanan itu sendiri, tetapi melalui mukjizat dan tanda-tanda banyak orang lebih terbuka untuk menerima Injil Yesus Kristus, terlebih karena hal-hal itu adalah merupakan janji Tuhan (Mrk.16:17-18).

Pekabaran Injil adalah bagaikan peredaran aliran darah di dalam tubuh manusia. Jikalau peredaran aliran darah di dalam tubuh kita baik dan lancar maka kita akan memiliki tubuh yang sehat, tetapi sebaliknya jika peredaran aliran darah kita tidak lancar dan terganggu maka kita akan menjadi orang yang sakit. Demikian juga dengan gereja, jika gereja tidak mengabarkan Injil maka gereja akan sakit dan lama kelamaan kalau tidak segera disehatkan kembali maka gereja akan mati. Jikalau semua orang Kristen ingin gerejanya hidup dan sehat serta bertumbuh maka semua orang percaya harus terlibat dan mendukung semua usaha pekabaran Injil yang dilakukan dengan berbagai macam karunia yang Tuhan berikan kepada gereja-Nya. Gereja yang tidak mengabarkan Injil adalah gereja yang siap untuk mati. Rasul Paulus berkata: "Karena jika aku memberitakan Injil, aku tidak mempunyai alasan untuk memegahkan diri, sebab itu adalah keharusan bagiku (1 Kor 9:16). 


\section{STT Kristus Alfa Omega}

STT Kristus Alfa Omega adalah sebuah sekolah Teologi yang berbasis seminari yang berlokasi di daerah BSB Semarang dan terletak di Kawasan Pendidikan \& social Blok E No.1 Perumahan BSB City, Kecamatan Mijen Semarang. Saat ini STT KAO dipimpin oleh seorang Ketua yaitu Dr. Gregorius H Soewito, M.Th. Program studi yang tersedia di STT KAO adalah untuk S.1, Teologi, PAK dan Musik Gereja, sedangkan untuk Prodi S.2 adalah Program Magister Teologi

STT KAO berada di bawah naungan Yayasan Pendidikan Kristus Alfa Omega yang berafiliasi dengan Gereja GBT Kristus Alfa Omega Semarang yang digembalakan oleh Pdt. Ir. Timotius Subekti. STT KAO menganut aliran Pentakosta Kharismatik dan setiap pengajarannya selalu mengemukakan karya Roh Kudus. Dosen dan mahasiswa yang tergabung di dalamnya adalah dari berbagai denominasi gereja tetapi semuanya menyesuaikan dengan doktri yang dianut oleh STT KAO. Ketua STT KAO sangat mendorong agar setiap mahasiswa untuk terus mengembangkan karunia Roh Kudus yang sudah didapat melalui pelatihan pengembangan karunia yang dilakukan di STT dalam periode waktu-waktu tertentu yang sudah disepakati antara pengurus dan peserta. Mahasiswa dibagi kelompok disesuaikan dengan karunia yang sudah dimiliki sehingga mempermudah untuk mengembangkannya. Dosen penanggung jawab dari program ini adalah Dr, Rudyanto CS, M.Th dan dibantu oleh beberapa dosen lainnya.

Anggota yang tergabung dalam pelatihan pengembangan karunia ini adalah dari berbagai tingkatan dan prodi. Berdasarkan pengamatan peneliti ada indikasi bahwa para peserta pada umumnya belum memiliki pengertian yang mendalam tentang karunia Roh Kudus. Anggota yang tergabung adalah mahasiswa yang memiliki keinginan untuk memahami karunia Roh Kudus dengan lebih mendalam sehingga mereka bisa memanfaatkan karunia itu di dalam pelayanan mereka. Pelaksanaan pengembangan karunia Roh Kudus ini baru pertama kali diadakan di STT KAO dan diharapkan dalam setahun akan mengalami perkembangan yang baik sehingga menarik minar mahasiswa yang belum tergabung. Pelatihan ini bersifat terbuka dan tidak eksklusif sehingga mahasiswa yang berminat bisa bergabung setiap waktu. Tujuan akhir dari pelatihan pengembangan karunia Roh Kudus ini adalah agar setiap mahasiswa yang tergabung di dalamnya memahami panggilannya untuk melakukan pemberitaan Injil melalui karunia yang Tuhan berikan kepadanya. 


\section{KESIMPULAN}

Kesimpulan dari hasil penelitian yang telah dilakukan dan saran-saran penting yang dianggap perlu disampaikan agar hasil penemuan ini menjadi bermanfaat bagi STT yang akan memanfaatkan program pemberdayaan karunia Roh Kudus di dalam pemberitaan Injil. Hasil penemuan ini secara khusus tentunya akan sangat bermanfaat untuk pemimpin Sekolah Tinggi Teologia Kristus Alfa Omega Semarang. Hasil penemuan yang ada bisa dipakai sebagai rekomendasi untuk lebih meningkatkan lagi efektivitas penjangkauan jiwa oleh mahasiswa.

Berdasarkan uji hipotesis, maka disimpulkan bahwa hipotesis nol yang berbunyi diduga minat Mahasiswa STT KAO tentang pengembangan karunia Roh Kudus dalam pelayanan pemberitaan Injil adalah pada kategori cukup $(=55 \%)$ atau sama dengan 93,5 , dinyatakan ditolak. Sedangkan hipotesis alternative yang berbunyi diduga minat Mahasiswa STT KAO tentang pengembangan karunia Roh Kudus dalam pelayanan pemberitaan Injil adalah tidak pada kategori cukup $(\neq 55 \%$ ) atau tidak sama dengan 93,5, dinyatakan diterima. Setelah dilakukan penghitungan seberapa besar nilai variabel X, maka disimpulkan bahwa nilai variabel X atau variabel Minat Mahasiswa STT KAO tentang Pengembangan Karunia Roh Kudus dalam Pelayanan Pemberitaan Injil adalah 94,4\% (kategori sangat tinggi).

Berdasarkan penghitungan pada hipotesis latar belakang responden yang paling berpengaruh pada variabel Minat Mahasiswa STT KAO tentang Pengembangan Karunia Roh Kudus dalam Pelayanan Pemberitaan Injil, maka disimpulkan bahwa latar belakang "lama berkuliah di STT KAO” menjadi latar belakang yang paling berpengaruh diantara tiga jenis latar belakang responden lainnya. Adapun besaran kuat pengaruh latar belakang "lama berkuliah di STT KAO” terhadap Minat Mahasiswa STT KAO tentang Pengembangan Karunia Roh Kudus dalam Pelayanan Pemberitaan Injil adalah 55,9 \% (kategori cukup). 


\section{DAFTAR PUSTAKA}

Douglas, J.D. Ensiklopedi Alkitab Masa Kini Jilid II. Jakarta: Komunikasi Bina Kasih OMF, 1995.

Hamon, Bill. 70 Alasan Berbahasa Roh. Jakarta: Nafiri Gabriel, 2013.

Hartono, Handreas. "Mengaktualisasikan Amanat Agung Matius 28 : 19-20 Dalam Konteks Era Digital.” KURIOS (Jurnal Teologi dan Pendidikan Agama Kristen) 4, no. 2 (2018): 169. www.sttpb.ac.id/e-journal/index.php/kurios.

Hinn, Benny. Selamat Datang Roh Kudus. Jakarta: Immanuel, 2004.

Schwarsz, Christian A. Pertumbuhan Gereja Yang Alamiah. Jakarta: Metanoia Publishing, 1999.

Tong, Stephen. Allah Tritunggal. Lembaga Reformed Injili Indonesia, 1993.

Wagner, C. Peter. Discover Your Spiritual Gift. Ventura, C. A: Regal Books, 2005.

Warren, Rick. Pertumbuhan Gereja Masa Kini. Malang: Gandum Mas, 1990. 